\title{
37. STRUCTURES WITHIN HOLE 917A, SOUTHEAST GREENLAND RIFTED MARGIN
}

\author{
Hervé Cambray ${ }^{2,3}$
}

\begin{abstract}
During Ocean Drilling Program Leg 152 at Hole 917A, downhole electrical images along with standard logs were recorded in the flood basalts that formed the seaward-dipping reflector sequences on the southeast Greenland margin. The Formation MicroScanner electrical images of the borehole are analyzed here in terms of geometry, and related to fractures and lava beds observed in the core. Despite the good core recovery for hard rocks (52\% average), these images are essential to provide a continuous and oriented record of structures vs. depth. More than 9000 structural events were mapped over $425 \mathrm{~m}$ of imaged flood basalts (22 per $\mathrm{m}$ on average). The steep fractures that dominate this interval are oriented mainly in an east-west strike direction with a seaward dip. The tilt of lava beds is also estimated from $15^{\circ}$ to $30^{\circ}$, and appears to be distinctly higher below 180 meters below seafloor. Both fracture and bed measurements show evidence of a slight clockwise rotation of the strike with increasing depth. These results address questions regarding deformation of this part of the southeast Greenland margin (mainly antithetical fracturing) to discuss a two-main-events tilting story associated with a rotation of the extensional direction.
\end{abstract}

\section{INTRODUCTION}

Ocean Drilling Program Leg 152 at $63^{\circ} \mathrm{N}$ successfully drilled into the landward feather edge of the seaward-dipping reflector sequence (SDRS) made up of flood basalts. Hole 917A is located on the East Greenland Shelf, approximately $50 \mathrm{~km}$ from shoreline. The general substratum of the flood basalts along southeast Greenland consists of a pre-rift Precambrian basement (Larsen, 1990). A wide zone of landward-dipping faults within the volcanic sequences is described based on seismic profiles (Fig. 1; Larsen, Saunders, Clift, et al., 1994). Hole 917A penetrated $779 \mathrm{~m}$ of basaltic, picritic, and dacitic lava flows overlying pre-rift sediments (Vallier et al., this volume). Flows range from a few meters to $52 \mathrm{~m}$ thick and were erupted in a subaerial environment during the Paleocene (Sinton and Duncan, this volume). The lava may be grouped into three main lithostratigraphic formations (Fig. 2). The Lower Series includes olivine-rich and olivine-free basalts; the Middle Series includes evolved basalts and metaluminous dacites; and the Upper Series includes a high proportion of primitive basaltic and picritic flows (Fitton et al., Chap. 28, this volume).

Although several models have been proposed (Eldholm et al., 1989; Larsen, 1990; Mutter et al., 1982; White and McKenzie, 1989), the structural development of volcanic rifted margins is not well known because of the huge volume of volcanics, erupted within the initial rift zones, that forms a cover over the early rift structures. Thus, apart from the characteristic crustal flexing associated with the apparently steady-state formation of the SDRS, the amount of faulting and other tectonic deformation of the crust during breakup at volcanic rifted margins is virtually unknown. Because only $52 \%$ of core was recovered and these cores were not oriented with respect to geographical coordinates, continuous and high-resolution borehole wall electrical images recorded by the Formation MicroScanner tool (FMS) at Hole 917A are essential to analyze and understand the structure of this unique deep section of the SDRS. A total length of $425 \mathrm{~m}$ of electrical images was recorded between 588 and 164 meters below seafloor (mbsf) over $779 \mathrm{~m}$ of basement available for logging.

${ }^{1}$ Saunders, A.D., Larsen, H.C., and Wise, S.W., Jr. (Eds.), 1998. Proc. ODP, Sci. Results, 152: College Station, TX (Ocean Drilling Program).

${ }^{2}$ Laboratoire de Mesures en Forage, Institut Méditerranéen de Technologie, 13451 Marseille cedex 20, France. cambray@ arbois.cerege.fr

${ }^{3}$ Laboratoire de Géologie du Quaternaire, UPR 1201 du CNRS, CEREGE, BP 80, 13545 Aix-en-Provence cedex 04, France.
Structural analysis of the electrical images across the three main volcanic series at Hole 917A consequently provides a rare opportunity to examine the syn- and post-rifting subsidence of the SDRS and to detail the process from continental rifting to open ocean.

The internal structure of the lava flows can be complex due to multiple deformation: (1) basalt cooling, (2) tectonic deformation, and (3) drilling-induced deformation. (1) Just after the emplacement, thermal cooling of subaerial basalts formed vertical retraction cracks with generally polygonal frame (columnar jointing; Budkewitsch and Robin, 1994). (2) The tectonic subsidence following the construction of the SDRS led to reactivation or activation of basement faults, which affected the overlying flows (Joppen and White, 1990). Tension faults may also have formed along the tilting axis related to the flexure of the margin. (3) Drilling-induced fractures may represent a response to the present regional stress field by formation or reactivation of fractures along the zone of weakness created by the drilling. However, formation of drilling-induced thermal fractures as reported from Hole 504B south of the Costa Rica Rift (Morin et al., 1990) is less likely, because of the much lower temperature difference between drilling fluid and formation in Hole $917 \mathrm{~A}\left(15^{\circ} \mathrm{C}\right.$ vs. $\left.115^{\circ} \mathrm{C}\right)$.

The present paper deals with the structure of the three main series logged at Hole 917A in order to study the tilting and fracturing evolution. The FMS images are analyzed in terms of geometry with a description of fracturing and bedding vs. depth. Logging depth scales are used for more accuracy and reliability (Fig. 2).

\section{STRUCTURES OBSERVED IN CORES}

Cores recovered at Hole 917A show well-preserved igneous structures including bedding and fracturing (Larsen, Saunders, Clift, et al., 1994).

Post-deposition tilting of the lava succession can be estimated from the dips of structures, such as sedimentary bedding, lava flow boundaries, flow banding, vesicular zones, and flattened vesicles. Core measurements from Hole 917A show consistency between sedimentary horizons with preserved bedding (dips ranging from $22^{\circ}$ to $25^{\circ}$ ) and the lavas containing a flow-banding feature. The latter forms regular, parallel, evenly spaced bands having dips ranging from $15^{\circ}$ to $30^{\circ}$. Flattened vesicles have readings similar to the flow-banding, whereas flow limits and vesicular zones are largely irregular. The evidence from the visual inspection of the cores as a whole suggests that the lava pile has been tilted at about $25^{\circ}$. 
A

Figure 1. A. Location of Site 917 with regard to the main structure of the North Atlantic Ocean. B. Interpreted seismic profile of the East Greenland Margin established at Site 917 (Larsen, Saunders, Clift, et al., 1994). LS = Lower Series; MS = Middle Series; US = Upper Series.

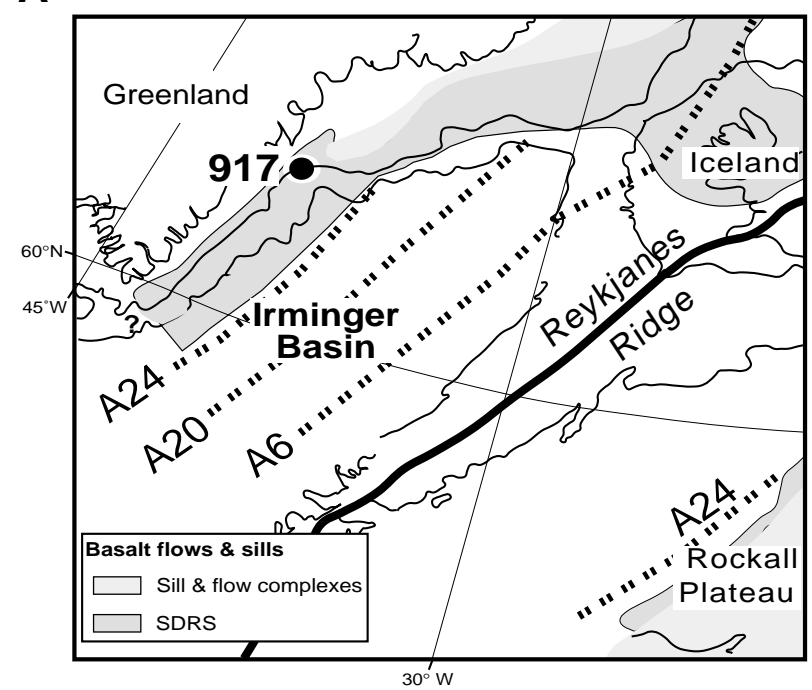

B

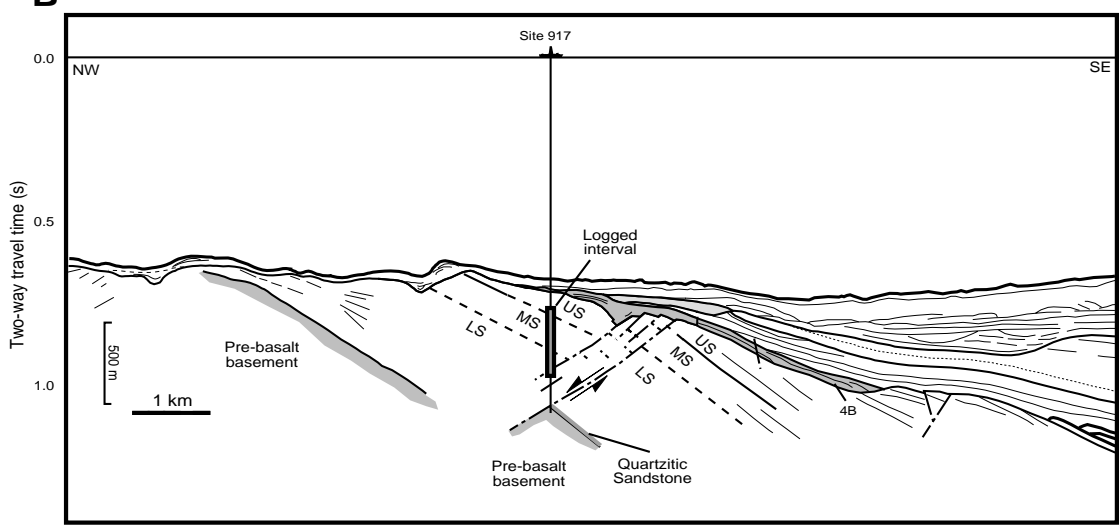

Fractures are found throughout the lava pile. They have variable orientations, and many are steep, with dips of about $70^{\circ}$ often noted. These fractures are lined and filled with secondary minerals, such as green clays, zeolites, and calcite. The fracturing is more intense in the lower parts of the lava pile, and slickensides are often developed on the clay fillings (e.g., Units 52, 66, 71, 74, and 75). In the more intensely fractured parts, the fractures often form two steep conjugate sets that tend to split the core apart. The slickensides mostly indicate dip-slip movements. In some cases, a component of strike-slip movements is observed, but evidence for major displacements is not apparent in the fractured rocks.

Zones in which the rocks have disintegrated into breccia (fault breccia associated with curved fractures consists of large angular basaltic clasts) or been transformed into mylonite ("mylonite zone shows a prominent streaky fabric, pseudotachylyte with a waxy lustre, and conchoidal fractures," p. 130 in Larsen, Saunders, Clift, et al., 1994) have been interpreted as faults. Such zones occur in the Lower Series in Units $71,72,73,74,75$, and 80 . The rocks adjacent to the breccia zones and mylonite have been highly fractured and sheared.

\section{LITHOSTRATIGRAPHY FROM DOWNHOLE MEASUREMENTS}

A combination of Schlumberger geophysical sensors and the FMS was run in Hole 917A (Larsen, Saunders, Clift, et al., 1994; Planke and Cambray, this volume).

The natural gamma-ray data in Hole 917A are particularly useful in identifying the nature of lava (Fig. 3). The most differentiated rocks yield high gamma-ray values, owing to their high $\mathrm{K}_{2} \mathrm{O}$ and thorium contents (e.g., 320-380 mbsf). Such a correlation is inferred because the electrical resistivity measurements do not show the presence of conductive K-rich alteration, another possible source of high gamma-ray intensity. The gamma-ray measurements made on core are in good agreement with those from the logging. The density, electrical resistivity, and acoustic data log data also correlate well (Fig. 3 ); though acoustic data show a high level of noise, they correlate extremely well with electrical resistivity data (high resistivity corresponding to high velocity). The velocity and the electrical resistivity profiles can be split into three major intervals: 180-260 mbsf (3.5 $\mathrm{km} / \mathrm{s}$ and $10 \Omega \mathrm{m}), 260-320 \mathrm{mbsf}(5 \mathrm{~km} / \mathrm{s}$ and $50 \Omega \mathrm{m})$, and $320-550$ mbsf (4.5-6 km/s and 10-80 $\Omega \mathrm{m})$. The sharp fluctuations observed mainly in the lower part of the hole are due to a bimodal structure within each single flow, where the vesicular upper part is opposed to the massive and gently fractured lower part. Thus, the FMS electrical images of the borehole wall provide complementary data, such as degree of vesiculation, alteration, and fracturing, to describe the boundary between flows and the structure of each flow (Fig. 4).

These high-quality logging data were studied to refine the lithostratigraphy of the Paleocene volcanic pile at Hole 917A. The absolute measurement of logging depth is more accurate and continuous than the core depth, especially at intervals of reduced core recovery (average core recovery was 52\% at Hole 917A). In fact, the original position of rock pieces within the cores is never precisely known and can be estimated only by a probabilistic model (Agrinier and Agrinier, 1994). This conclusion is enforced by the significant changes between this precisely established lithostratigraphy and the core observations and measurements (Fig. 2; Demant et al., 1995). 

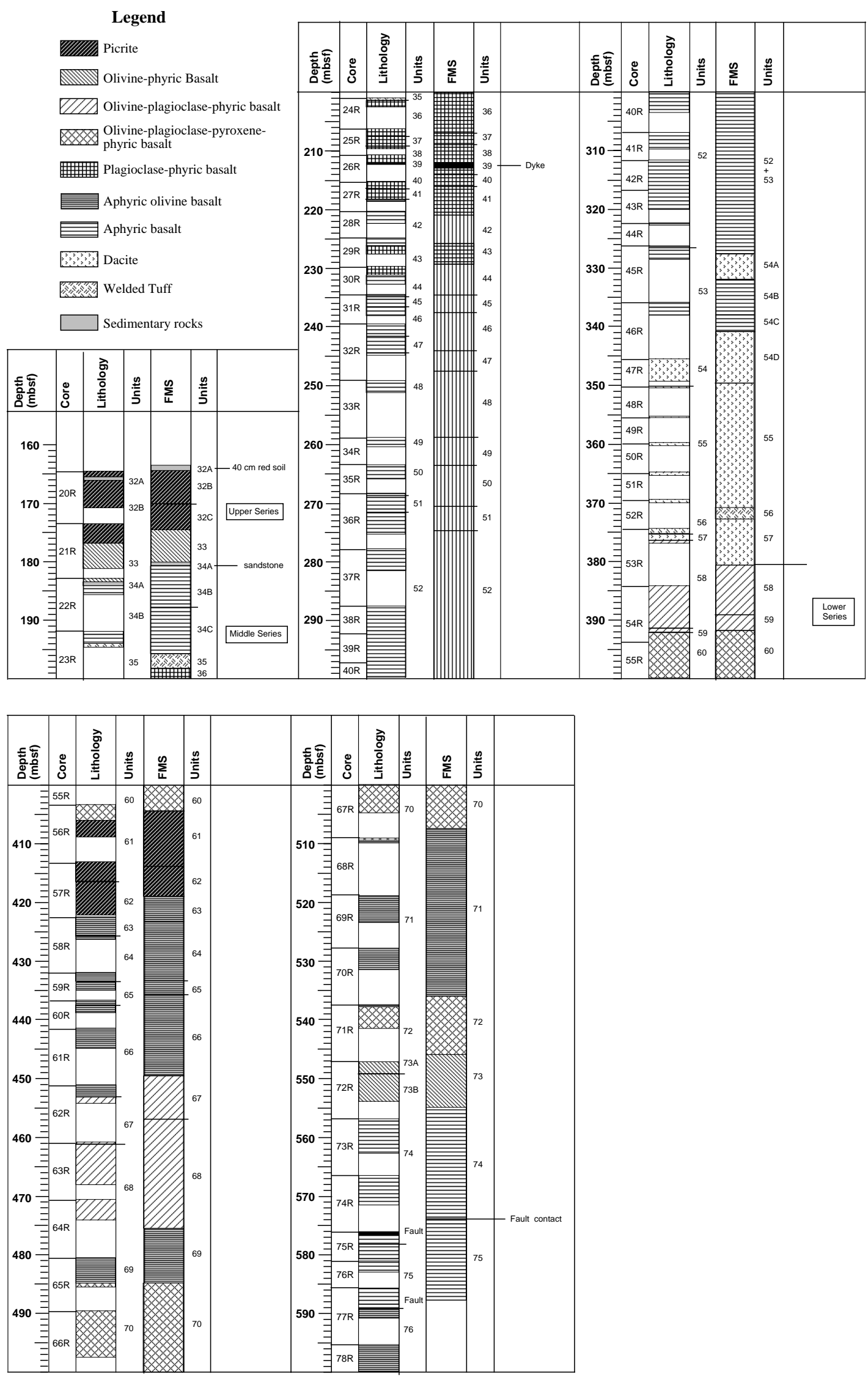

Figure 2. Shipboard and revised lithostratigraphies at Hole 917A; revised stratigraphy is based on a combination of core descriptions and FMS image analyses (Demant et al., 1995). Revised stratigraphy provides an absolute logging depth for the limits between units. On the basis of FMS images, Units 32 and 34 were each subdivided into two subunits, Unit 54 was divided into four subunits, and Unit 53 was not detected. 


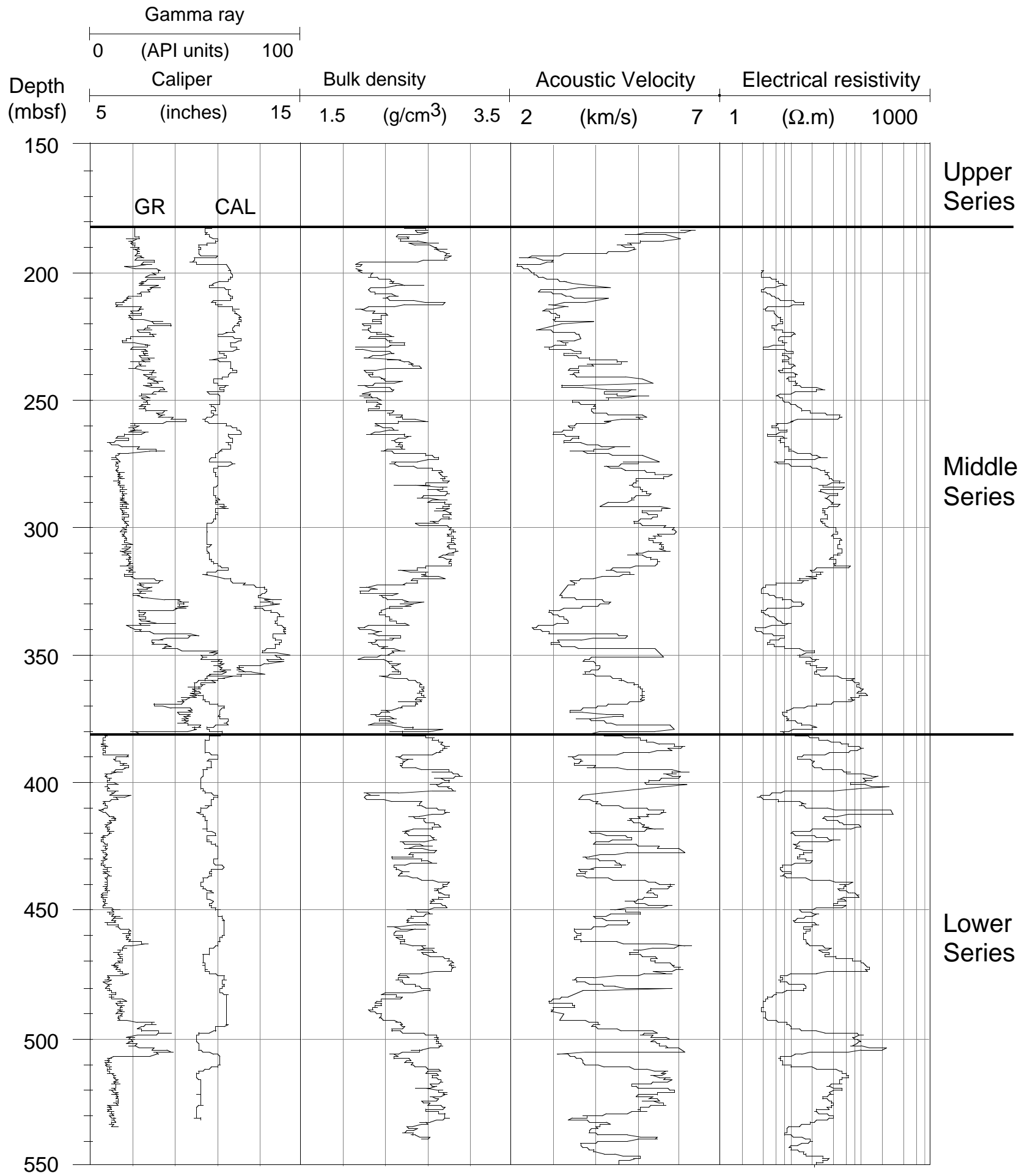

Figure 3. Summary log of Hole 917A: from left, NGT (natural gamma-ray tool), HLDT (high-temperature lithodensity tool), SDT (sonic digital tool), and DIT (dual induction tool). Lithostratigraphic formations (Lower Series, Middle Series, and Upper Series) shown.

\section{STRUCTURAL ANALYSIS FROM FMS ELECTRICAL IMAGES}

The FMS creates an image of the borehole wall by mapping electrical conductivity variations into the rock with an array of small, pad-mounted electrodes (Lüthi and Banavar, 1988). The slim-hole configuration developed for ODP (Pezard et al., 1990) uses four pads, each with 16 buttons; a single pass of the tool maps about $22 \%$ of the 25.4-cm-diameter borehole. Each electrode is oriented in space with sets of three-axis accelerometers and three-axis flux-gate magnetometers, making it possible to derive the strike and dip of any geological structures vs. depth. During logging, current flows from the lower section of the tool into the rock formation, and then to a return electrode located at the top of the sonde. A constant difference of electrical potential is held between each of the electrodes and the remote return. As the conductivity of the rock formation varies in front of each 


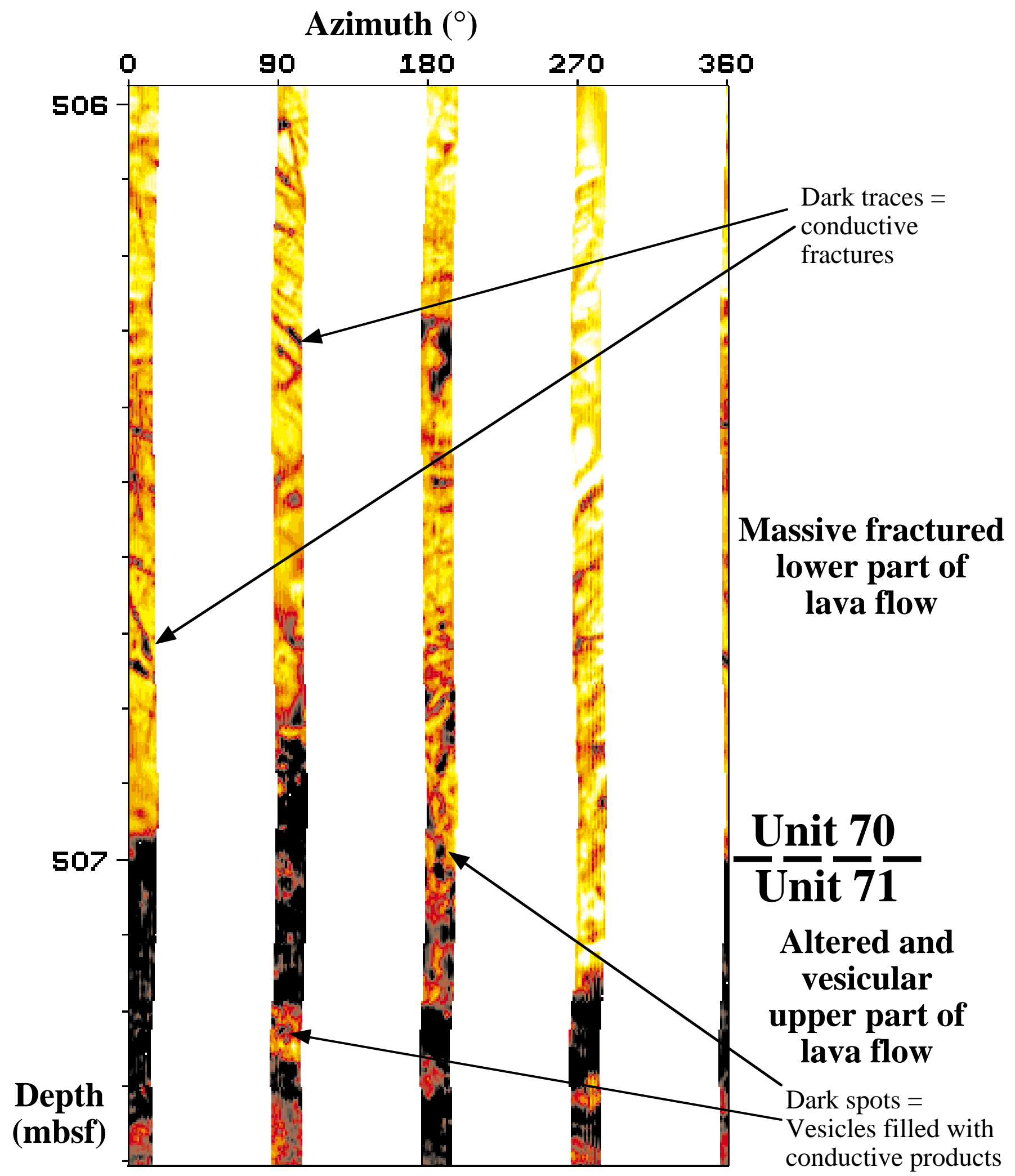

Figure 4. Oriented FMS image showing flow boundary, textures, and fractures. Dark corresponds to conductive and light to resistive intervals. 
electrode during recording, a variable current is injected for each electrode into the rock to satisfy the constant potential condition. The button current is thus recorded as a curve representing relative changes in microresistivity caused by either (1) varying electrolytic conduction as a function of fluid type and temperature, or changes in grain and pore volume, size, and geometry; or (2) cation exchanges onto clay mineral surfaces.

Because of the electrode geometry, the tool has a moderately shallow depth of investigation (a few centimeters beyond the borehole wall). FMS data are recorded each $2.5 \mathrm{~mm}$ as the tool moves up the borehole; vertical resolution of individual features is below centimeter scale. The tool can, however, detect thinner features (down to a few microns), provided they have sufficient resistivity contrast with the surrounding matrix. The images recorded with the FMS show conductivity changes resulting from bed structures and boundaries, as well as from the presence of fractures, either open or mineralized. Conductive events are normally reproduced with darker shades, and resistive ones in white (Fig. 4).

Only 16 gray tones or colors are normally represented in hard copies of the images and often provide only a reduced resolution and dynamic range compared to the original resistivity data. As a consequence, the FMS images preferably should be investigated on a workstation that allows access to the full range of data (e.g., to enhance or to zoom in and out of images). The images presented in this paper are, therefore, of lower quality than those used to analyze the data set.

\section{Data Processing}

Data processing is required to convert the raw data into a grayscale (or color-scale) image representative of conductivity changes. Data processing includes conversion of raw data to variable-intensity gray or color images. Because the supposed "constant" difference of potential is actually regulated during recording to adapt to rock resistivity to produce the best possible contrast, FMS images do not represent a direct map of electrical conductivity of the borehole wall.
Such a map can only be obtained after calibration of the FMS images with absolute electrical resistivity measurements with a similar depth of penetration into the rock, such as that of the shallow resistivity measurement (SFLU). FMS processing basically consists of two main phases: data restoration and resistivity calibration.

\section{FMS Image Analysis}

After being processed and calibrated, the images were analyzed with FracView, a Schlumberger interpretative software, which allows an interactive display and interpretation of oriented FMS images. The fracture analysis method was developed by Lüthi and Souhaité (1990) and is aimed at providing a quantitative evaluation of "fracture aperture" from the calibrated electrical images. This evaluation is based on finite-element modeling of the theoretical response of the FMS in front of conductive anomalies such as fractures.

Analyzing fractures on FMS images consists of mapping traces showing a contrast of conductivity to the surrounding rock. Any plane intersected by a cylindrical borehole is represented by a sinusoid on a depth-azimuth plot. The dip angle is a function of the amplitude of the sinusoid, and the dip direction (plunge) is given by the lowermost point of the trace. Planes dipping up to $80^{\circ}$ can be detected by the four pads (i.e., visible on four images). Near vertical fracture are typically visible on two images only. As a consequence, FMS images mapping is likely to underestimate the presence of nearly vertical events. Furthermore, a vertical borehole will preferably encounter more shallow dipping than steeply dipping fractures (Newmark et al., 1985). Thus, the fact that a very large percentage of the events imaged at Hole 917A are high angle events, with an average dip at about $60^{\circ}$, probably reflects a preponderance of steep fractures at this site.

Other problems encountered during the analysis of FMS data are related to borehole conditions and the contrast of magnetic intensity between the lava flows. The quality of the FMS images can be affected by the enlarged hole size. In such intervals, pads of the FMS tool lose contact with the borehole wall and provide poor resolution records. Conditions are good in Hole 917A except between 360 and
Figure 5. Total magnetic field vs. depth at Hole 917 A recorded by the three-component flux-gate magnetometer of the FMS tool.

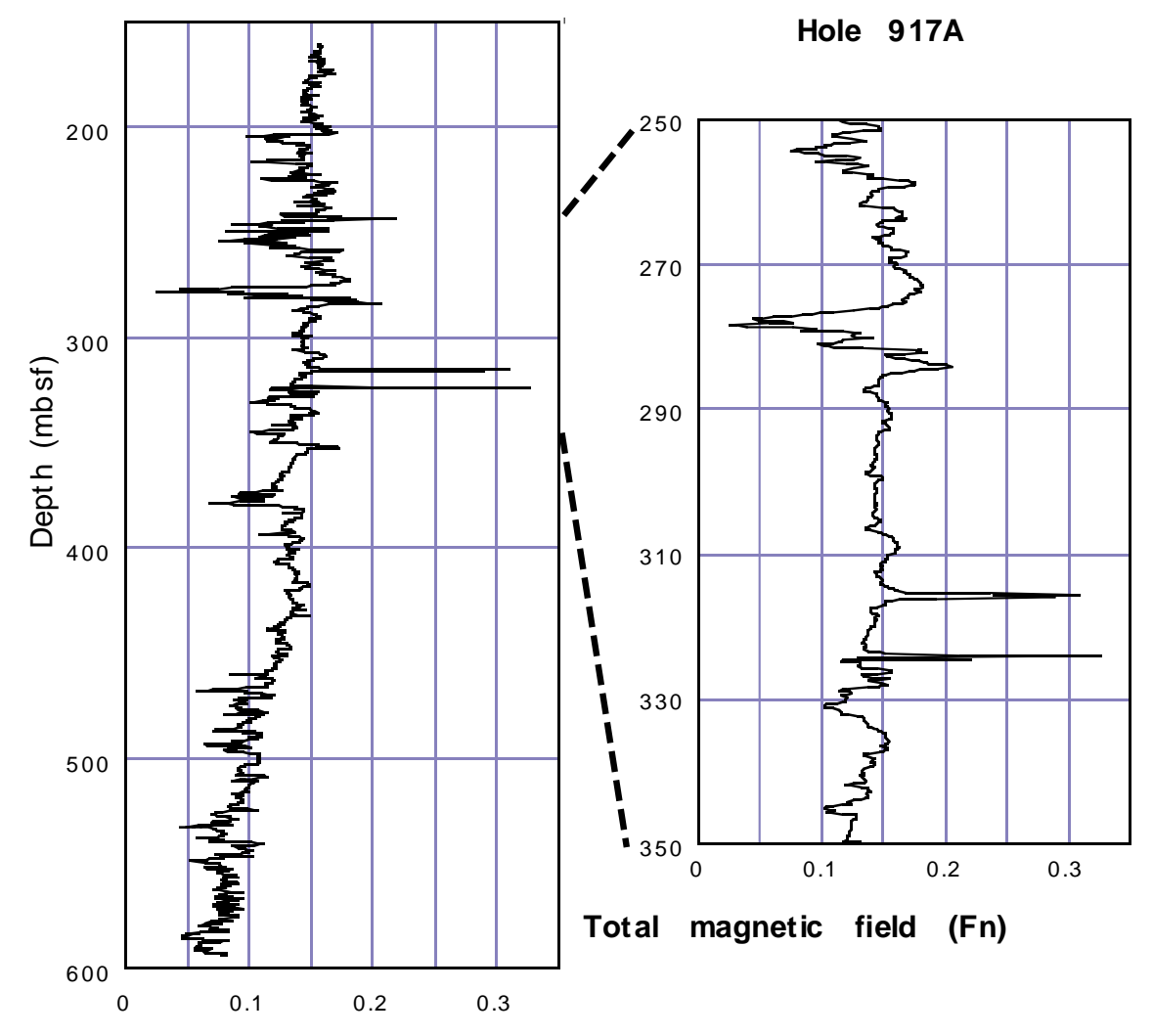


320 mbsf, as shown by the caliper measurements (Fig. 3). This interval corresponds to the occurrence of dacitic flows, but the hole size variations peak at $14 \mathrm{in}$, well under the maximum aperture of the FMS arms (16 in), and in agreement with this a fair data quality is maintained in this interval, too. The FMS electrical images are oriented in space with sets of three-axis accelerometers and three-axis fluxgate magnetometers. In case of high magnetic contrast in the formation logged, the magnetometer may be saturated and not able to record the true magnetic field, resulting in the loss of tool orientation. The volcanic pile drilled at Hole 917A comprises highly magnetized zones: the magnetic susceptibility measured on cores reaches 9000 cgs at the bottom of Unit $53(325 \mathrm{mbsf})$ and $3500 \mathrm{cgs}$ at the top of Unit 52 (280 mbsf), whereas the background noise is under $1000 \mathrm{cgs}$ (Larsen, Saunders, Clift, et al., 1994). The total magnetic field recorded by the FMS tool is plotted in Figure 5. The amplitude variations are reliable except at 325, 315, and 285-280 mbsf. In these sections of the hole, the total magnetic field was not measured because of the high magnetic intensity of lava as compared with the surrounding flows. As a consequence, it was not possible to derive the strike and dip of geological structures in these particular depth intervals.

Potential fractures are determined using contrast of conductivity. Line sharpening and trace connectivity tests are performed to accurately map the fractures after manual identification, and apertures are computed along each trace for all fracture locations. Although the structures observed in the core (veins, open fractures, microfaults, induced fractures, etc.) cannot be distinguished directly from FMS images because they are represented only in terms of electrical conductivity, a first order classification based on geometry can be made. In all, 9347 features were mapped from 588 to $164 \mathrm{mbsf}$ (22/m on average).

\section{Present Stress Field and Drilling-Induced Fracturing}

The difference between the two perpendicular calipers of the FMS provides a measurement of borehole shape. The hole size measured by the FMS shows that the borehole was in excellent condition, with most values between 10.2 and 11.8 inches and an average of 11 inches in diameter (Fig. 6). Throughout the hole, the west-east oriented caliper always gave a smaller diameter than the north-south one (Fig. 6). As a consequence, elliptical elongation of the borehole is roughly along a north-south axis. Although the depth-azimuth plot does not define these directions precisely, a histogram of this elongation provides a much clearer description (Fig. 6), with azimuth orientation of elongation at about $\mathrm{N} 15^{\circ} \mathrm{E}$.

The presence of an elliptical borehole shape is traditionally interpreted in terms of ruptured surfaces of the borehole wall or breakouts (Bell and Gough, 1979), with the strike of the breakout along the long axis of the borehole pointing toward the minimum horizontal stress direction. By sorting the structural events vs. dip, subvertical features are extracted from the whole set of data $\left(\operatorname{dip}>80^{\circ}\right)$. A total of 111 subvertical traces described over the analyzed interval are assumed to correspond to post-drilling rupturing of the borehole wall because only very few vertical planes are found within the core itself. The two main strike directions of subvertical planes, respectively $\mathrm{N} 20^{\circ} \mathrm{E}$ and $\mathrm{N} 100^{\circ} \mathrm{E}$ (Fig. 7), might be interpreted in terms of, respectively, compressive breakouts that fit the orientation of hole elongation and in terms of tensile cracks for those that are perpendicular. As a consequence, $\mathrm{N} 15^{\circ}-20^{\circ} \mathrm{E}$ was proposed to represent the local minimum horizontal stress direction implying that the present-day maximum horizontal stress within the flood basalts is oriented at $\mathrm{N} 105^{\circ} \mathrm{E}$ (i.e., close to the plate motions away from the adjacent Reykjanes Ridge; Srivastava and Tapscott, 1986).

Detailed examinations of the ruptured vertical surfaces show that they are concentrated along the fault zones (e.g., between 590 and 580 mbsf; Fig. 8), where the strength of the basalt might be influenced by the presence of multiple preexisting fractures and veins, and hence, be more prone to induce drilling deformation.
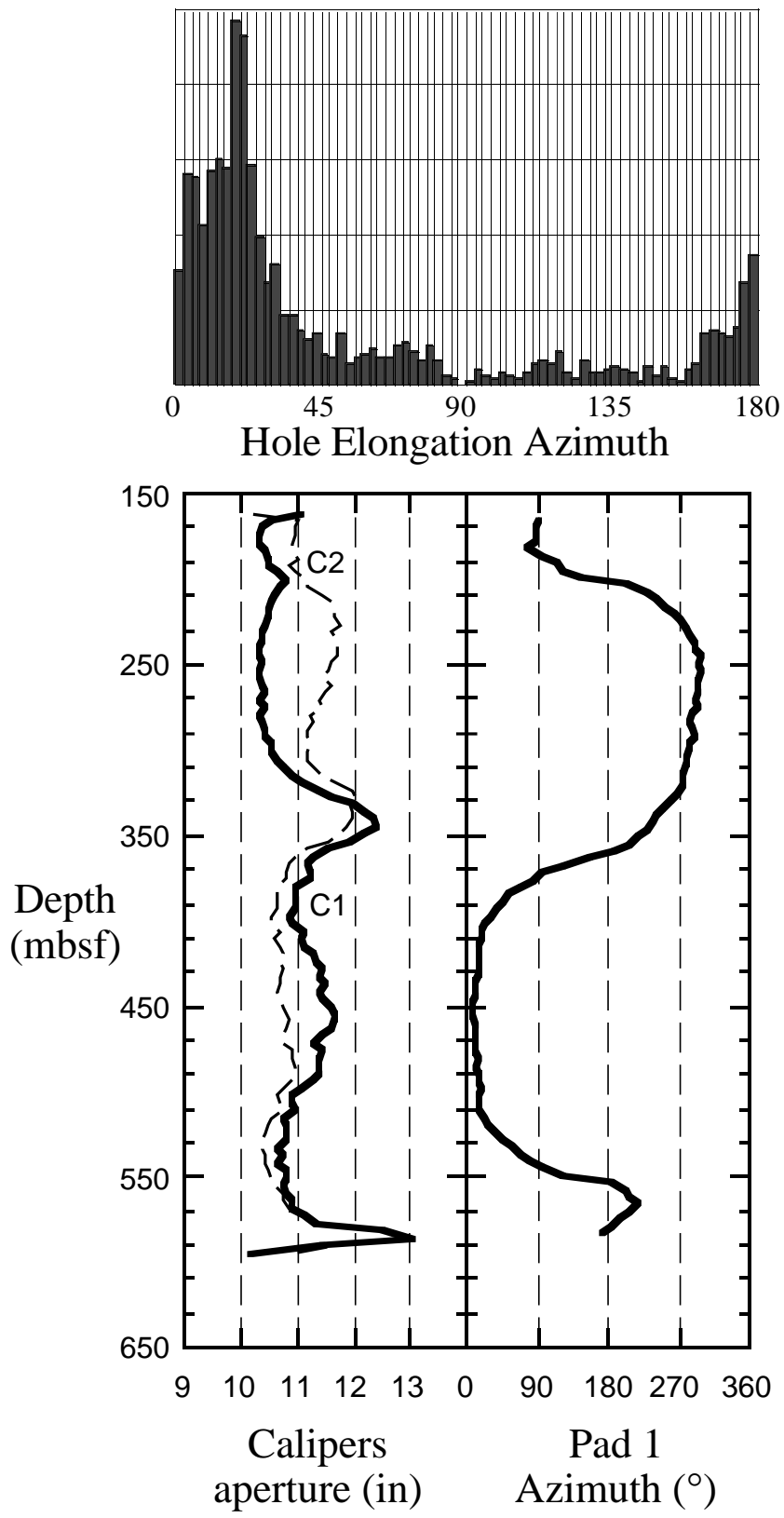

Figure 6. Charts illustrating the constant hole elongation direction as observed with FMS calipers in Hole 917A. The tool rotated $90^{\circ}$ at 350 mbsf. The largest hole diameter remains oriented close to the north-south axis $\left(\mathrm{N} 15^{\circ}-20^{\circ} \mathrm{E}\right)$.

\section{Structural Analysis}

\section{General Trends}

At Hole 917A, 9347 events for the logged interval from 588 to 164 mbsf were mapped. The contour plot of dip directions for the whole set of data shows a concentration of planes striking around a west-east direction $\left(\mathrm{N} 90^{\circ} \mathrm{E}\right)$ and dipping $64^{\circ} \mathrm{S}$ (Fig. 9). The 4215 events for the Lower Series show a similar trend $\left(\mathrm{N} 90^{\circ} \mathrm{E} 60^{\circ} \mathrm{S}\right)$, whereas for the Middle Series (4666 events) the dip angle is steeper with more dispersion of data $\left(\mathrm{N} 87^{\circ} \mathrm{E} 64^{\circ} \mathrm{S}\right)$. The results (464 events along a 17-m-long interval) for the Upper Series are scattered. The contour plot of dip directions for the Upper Series shows a concentration of planes striking around $\mathrm{N} 60^{\circ} \mathrm{E} 18^{\circ} \mathrm{NW}$ and $\mathrm{N} 86^{\circ} \mathrm{E} 22^{\circ} \mathrm{N}$, with secondary clusters at $\mathrm{N} 30^{\circ} \mathrm{E} 70^{\circ} \mathrm{SE}, \mathrm{N} 168^{\circ} \mathrm{E} 54^{\circ} \mathrm{E}, \mathrm{N} 152^{\circ} \mathrm{E} 20^{\circ} \mathrm{NE}$; 
Figure 7. Strike and strike histogram of vertical fractures (dip > 80 ${ }^{\circ}$ mapped at Hole 917A.
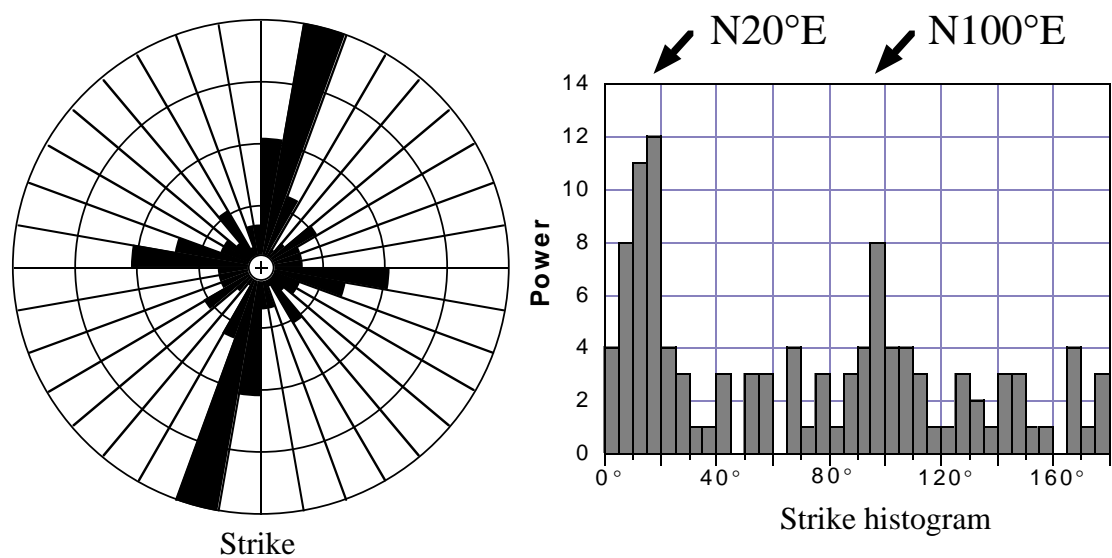

Vertical planes (111 events, 588-164 mbsf, dip $>80^{\circ}$ )
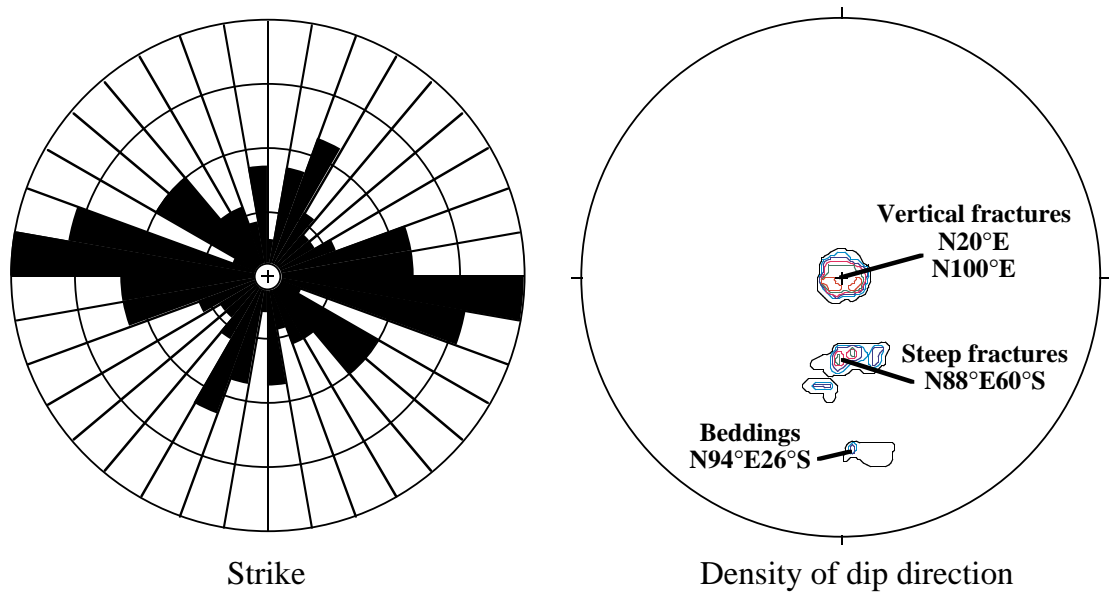

Density of dip direction (Schmidt lower hemisphere)
Figure 8. Strike and density of dip directions of planes mapped along a fault zone between 590 and 580 mbsf at Hole 917A.

\section{Fault zones (103 events, 590-580 mbsf)}

and $\mathrm{N} 40^{\circ} \mathrm{E} 17^{\circ} \mathrm{SE}$. Low-angle features dominant in this interval are assumed to mainly correspond to the stratigraphic bedding of the lava flows.

\section{Dike}

At 213 mbsf, Hole 917A crossed the only dike present in the volcanic sequences (Unit 39). This dike strikes around $\mathrm{N} 96^{\circ} \mathrm{E}$ and dips $58^{\circ} \mathrm{S}$ (Fig. 10). Structural data originated from a single dike should be used with caution, because deformation responsible for its emplacement may be controlled by combined effects of regional stress and magmatic pressure (e.g., Pollard, 1987). However, the observed dike orientation fits the general trend observed in the whole set of structural data, and the dike strikes along the present maximum horizontal stress as defined by elongation of the borehole wall and orientation of induced fractures $\left(\mathrm{N} 105^{\circ} \mathrm{E}\right.$; Figs. 6, 7).

\section{Bedding and Tilting}

Syn- or post-deposition tilting of the lava succession may be deduced from the dips of three main structures, the lava flow boundaries, the sedimentary bedding and the flow-banding. Originally, these structures may not necessarily have been strictly horizontal and thus should be used with caution. However, if several of these structures show consistent dips over large depth intervals, one might de- duce the tilting evolution of the flood basalts, from data that, like the present, are statistically significant. The whole set of measurements was sorted to extract structural data related to the dips of lava flows. The detailed seismic data provided evaluation of the dips vs. depth (Larsen, Saunders, Clift, et al., 1994). In the vicinity of Hole 917A, the general apparent dip of the basalt surface at shallow depth is between $5^{\circ}$ and $10^{\circ}$ toward the southeast. At deeper levels, the seaward tilting of the basalts reaches a maximum of $20^{\circ}-25^{\circ}$, though dip estimation is less well controlled by seismic data at depths. Accordingly, all the planes with a dip higher than $40^{\circ}$ were removed from the whole set of events, to enhance data that could reflect bedding planes (Fig. 11). The dip directions show coherent values for the older units with a dip of about $30^{\circ}$ to the southwest and south for the Lower Series (see also Fig. 8) and to the southwest and southeast for the Middle Series. On the other hand, the results are dispersed for the Upper Series with dominance of landward dipping of about $20^{\circ}$ to the north. A secondary cluster shows more coherent data with dips of about $15^{\circ}$ to the southeast. To more precisely determine the tilting of the lava flows, I selected depth intervals where flow-banding is well expressed on the FMS images. Flow-banding directions are identified and measured in the pahoehoe flows for the Lower Series and the aa flows for the Middle and Upper Series (Fig. 12). Results show consistent seaward-dipping directions for Unit 32B between 174 and 171 mbsf $\left(\mathrm{N} 42^{\circ} \mathrm{E} 16^{\circ} \mathrm{SE}\right)$ belonging to the Upper Series, whereas the features for the other units are landward dipping. Furthermore, clear 


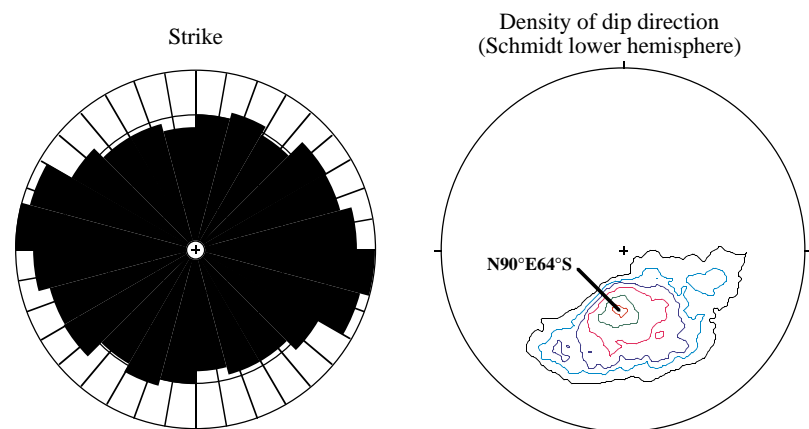

All series (9347 events, 588-164 mbsf)
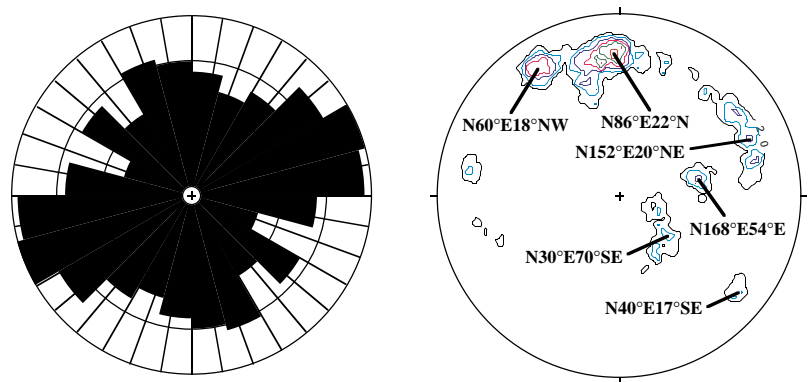

Upper Series (464 events, 181-164 mbsf)
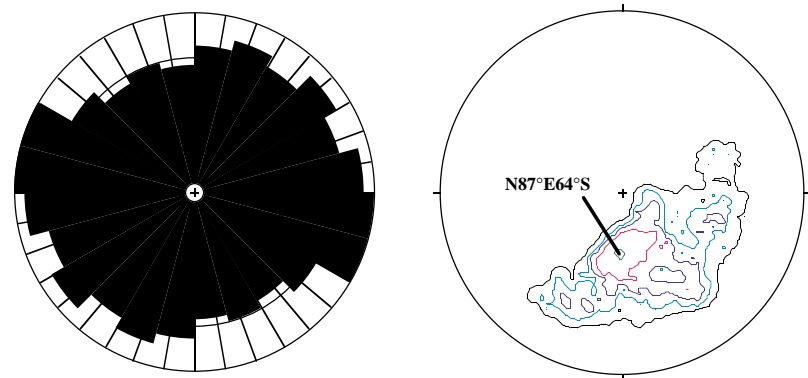

Middle Series (4666 events, 380-181 mbsf)
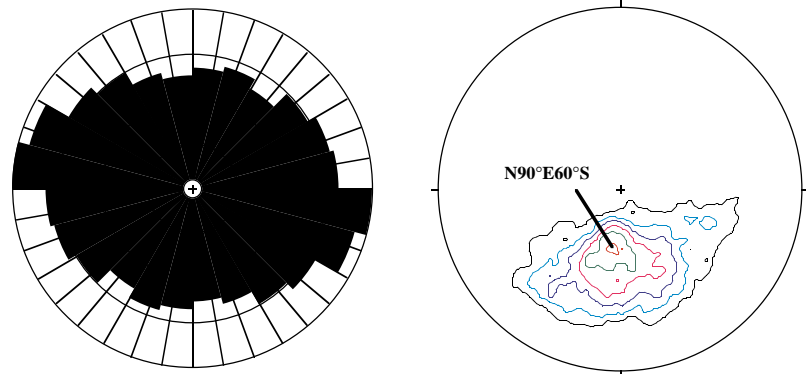

\section{Lower Series (4215 events, 588-380 mbsf)}

Figure 9. Strike and density of dip directions of planes mapped at Hole 917A sorted vs. the lithostratigraphic formations.

landward dip is measured from the sandstone level located between the Middle and the Upper Series (Fig. 12).

\section{Fractures}

Except for the scattered features observed in the Upper Series, the logged interval is characterized by the predominance of steep events with a dip azimuth concentrated in the southeast quadrant. Comparing with the core, these steep planes might be associated with the steep fractures filled with secondary minerals and observed through- out the lava pile (Larsen, Saunders, Clift, et al., 1994). Interestingly, the strike of fractures points out a slight clockwise rotation with increasing depth (Fig. 9). To further examine this trend, I identified depth intervals where fracturing is particularly well expressed on the FMS electrical images. These selected intervals mostly correspond to the massive lower part of thick flows. In the upper part of the flows, occurrences of vesicles and alteration generally overprint the electrical signals related to fractures and identification is less reliable. There is some variability in fracture orientation and dip with depth (Fig. 13). Dip azimuth is dominantly to the south in the Lower Series (see also Fig. 8), but shows some trends to the southeast in the Middle Series. These patterns of variation in fracture orientation with depth are consistent with those observed for the bedding orientation. A possible explanation could be a rotation of the tilting axis during the deposition of the basaltic flows pile. The dip angle is steep in all the fracture zones and shows a slight increase of about $5^{\circ}$ to $8^{\circ}$ in the Middle Series vs. the Lower Series. This difference in dip could be interpreted as due to tilting of the lava piles. Assuming that the dip of fracture was originally steeper, one might suppose that the tilting is more severe for the older lava flows of the Lower Series compared to the more recent ones (i.e., the tilting event began before deposition of the flood basalts was completed).

A key point concerns the potential origin of these steep fractures. They might be fracturing from extension of the margin or tilted columnar cooling joints. The structure of subaerial basaltic flows is commonly marked by columnar jointing formed by thermal retraction during cooling of lava. Cooling cracks often propagate inward and divide the rocks into prismatic columns (Budkewitsch and Robin, 1994). Shape of the prisms is close to polygonal pattern depending on several factors, such as nature and thickness of the flow, intensity and direction of the thermal gradient, presence of meteoric water during cooling. Field observations show a well expressed prismatic frame at the bottom of the flows and coarser patterns at the top (Hardee, 1980). Consequently, a possible source of fracturing might be cooling deformation. The structural results and especially orientation of the steep fractures do not confirm this hypothesis (Fig. 9). An original subvertical fracturing should show north-northwest dip with the subsequent south-southeast tilting. Furthermore, this fracturing should have affected at least one third of each lava flow with a regular distribution of cracks. This particular pattern was not observed either on cores or on the FMS images. The apparent absence of cooling fractures at this hole suggests that the lava flows were not thick enough to develop such columnar jointing. Even within the thickest flow (Unit 52, 327$275 \mathrm{mbsf}$ ), no evidence allows us to identify cooling fracture from structural data (Fig. 13) or from observations of cores and FMS electrical images.

These steep seaward-dipping planes therefore may have a tectonic origin possibly due to extension. However, the structural analysis of the borehole images does not show any direct evidence of the main, landward-dipping faults (Fig. 1). Apparently these main faults primarily affected the flood basalt out of the logged interval (e.g., at 628$629 \mathrm{mbsf}$ as observed in the cores), whereas above $588 \mathrm{mbsf}$, the FMS images only recorded a possible indirect consequence. Thus, the seaward-dipping steep fractures may represent an antithetical fracturing associated with the movements along these deep faults. The Upper Series is only slightly affected by this steep fracturing (not well defined secondary cluster at $\mathrm{N} 30^{\circ} \mathrm{E} 70^{\circ} \mathrm{SE}$; Fig. 9) and is steeper compared to the Lower and Middle Series. The top of flood basalts is, however, clearly cut by the fault (Fig. 1). As a consequence, we may assume that the main extensional component that controlled this antithetical fracturing was mainly active before the setting of the Upper Series. Furthermore, a noticeable counterclockwise rotation of the structure was observed from the Lower to the Middle Series, which especially concerns the steep seaward-dipping fractures with an average dip switching from the south to the southeast. Such feature also suggests change in the main direction of extension during the setting of the flood basalts. 


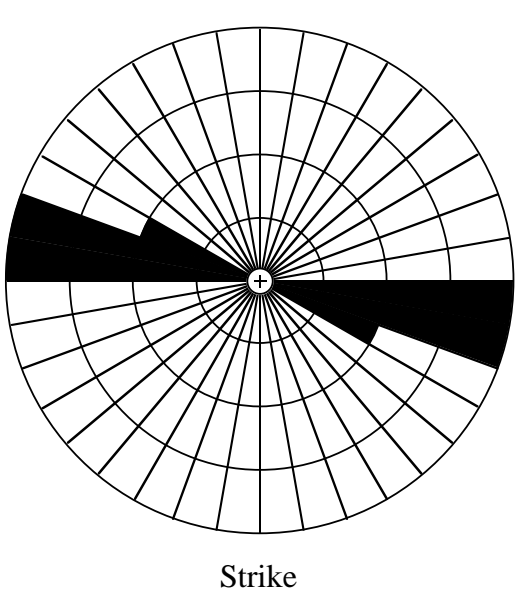

Figure 10. Strike and density of dip directions of four planes corresponding to the dike crossed at Hole 917A at 213-212 mbsf (Unit 39).

\section{Dike (Unit 39, 4 events, 213-212 mbsf)}

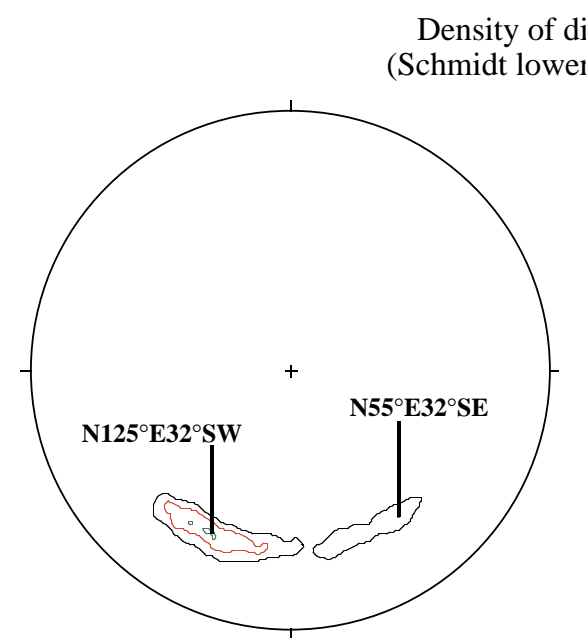

All series

(5007 events, 588-164 mbsf)

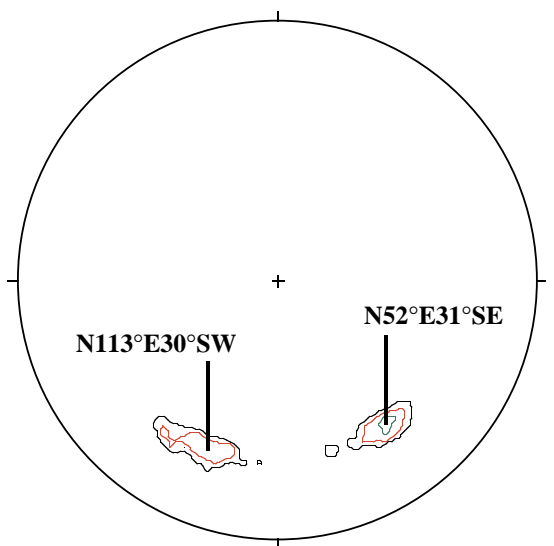

Middle Series (2459 events, 380-181 mbsf)

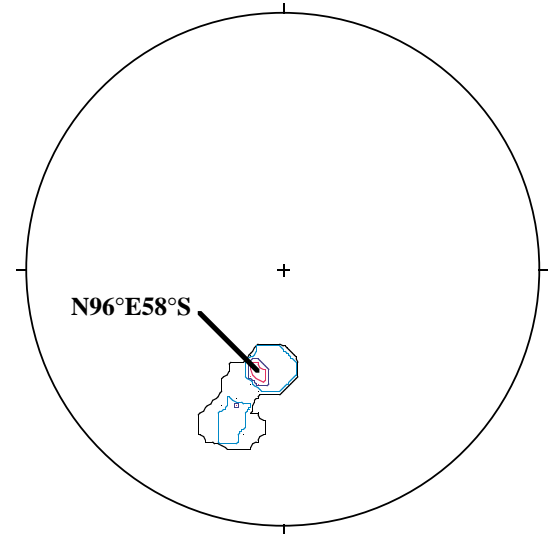

Density of dip direction (Schmidt lower hemisphere)
Figure 11. Density of dip directions of moderately dipping planes $\left(\operatorname{dip}<40^{\circ}\right.$ ) mapped at Hole 917A sorted vs. the lithostratigraphic formations.

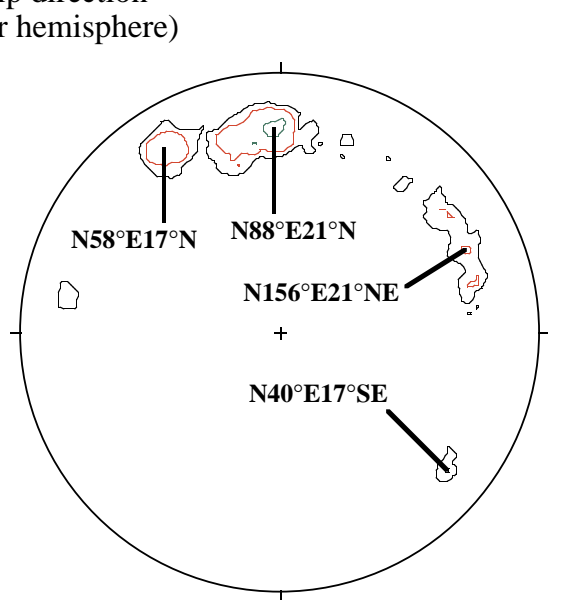

Upper Series (310 events, 181-164 mbsf)

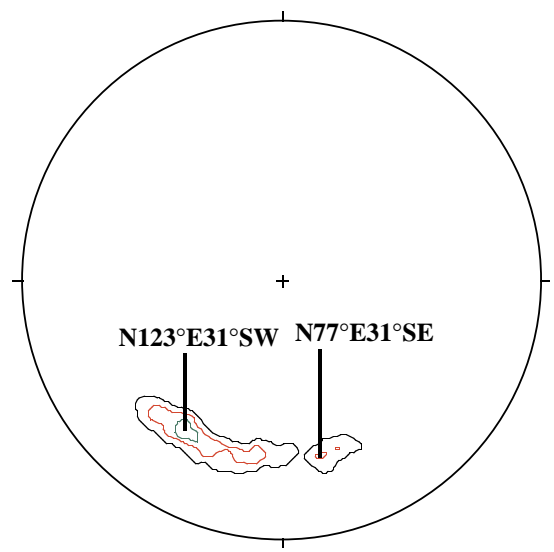

Lower Series (2236 events, 588-380 mbsf) 
Density of dip direction

(Schmidt lower hemisphere)

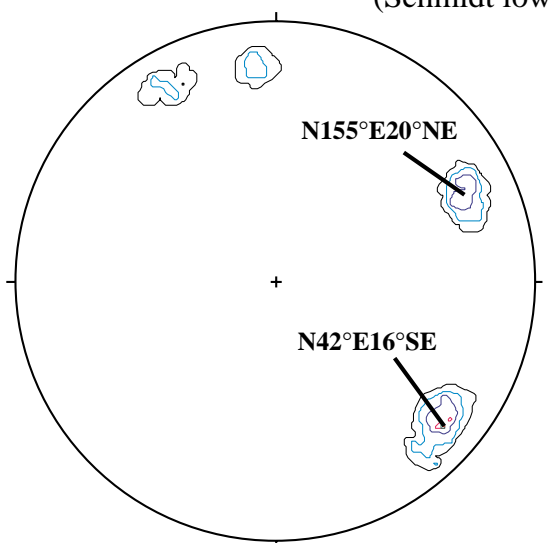

Flow-banding (77 events, 174-171 mbsf)

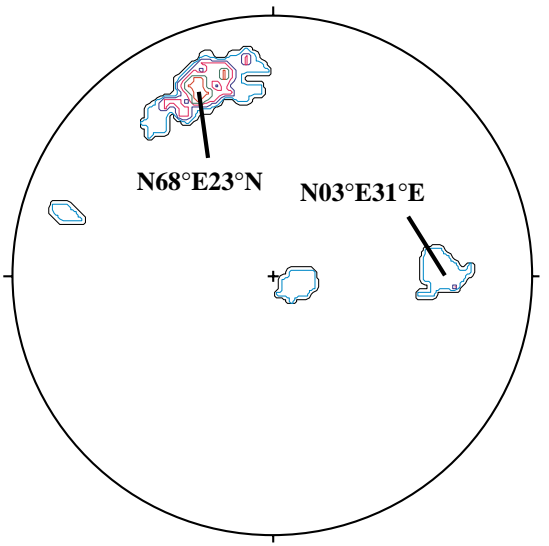

Flow-banding (26 events, 413-410 mbsf)

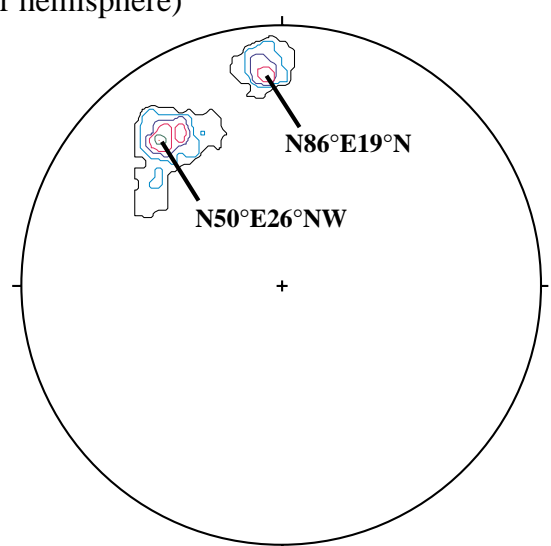

Flow-banding (28 events, 237-236 mbsf)

\section{DISCUSSION}

The landward- and shallow-dipping features observed mainly in the Upper Series are difficult to reconcile with the quite clear seismic image of these. However, the number of planar events mapped for the Upper Series is relatively small (10 times smaller when compared with the Lower and Middle Series), and results may not be statistically reliable. Also, differences in the nature of the lava flows (aa flows dominate in the older units, whereas pahoehoe flows are dominant in the Upper Series; Larsen, Saunders, Clift, et al., 1994) may have contributed to the marked difference in dip attitudes. One may suppose that the larger thickness and possibly the structure of the aa flows is more adequate to record the tilting of the SDRS (i.e., internal flow structures originally were close to horizontal). This may not have been the case for the thinner pahoehoe flows of the Upper Series, and secondary processes (e.g., lava tube formation, lava channeling, and pressure ridges) may have disrupted the lava bedding (Fig. 12).

The structural study performed from the FMS images at Hole 917A allows me to propose a model for the tectonic evolution of the flood basalts. Given the paleomagnetic data (Larsen, Saunders, Clift, et al., 1994) and the radiometric ages (Sinton and Duncan, this volume), the Paleocene lava pile recovered at Hole 917A accumulated during a period of no more than about 5-6 m.y. and possibly less. During this period, extension is supposed to have taken place as evi- denced by the antithetical fracturing in the Lower and Middle Series and by the tilting of the volcanic sequences. Furthermore, the data show a slight progressive rotation of the strike of the steep seawarddipping fractures from the Lower Series to the Middle Series, suggesting a two-component tilting model: an initial $10^{\circ}-15^{\circ}$ tilting of the Lower and Middle Series along a west-east axis followed by a $10^{\circ}-15^{\circ}$ tilting of the whole volcanic sequences along a northeastsouthwest axis. This model is consistent with the lower dip of lava flows $\left(15^{\circ}\right.$ seaward $)$ and the near absence of steep fractures related to the active faulting in the Upper Series. One may consequently suggest that the major extensional episode took place during and just after the setting of the Lower and Middle Series and was followed by a shift in stress regime toward orthogonal extension around the developing oceanic rift. The slight rotation observed in the strike of steep fractures may be the result of the two-step tilting, but a component of strike-slip movements and crustal rotation is also possible.

The structural development indicated by the FMS data may be interpreted as follows. During and just after the deposition of the Lower and Middle Series, a north-south extension is responsible for normal faulting associated with antithetical fracturing, and associated crustal thinning induced a tilting of the flows toward the south. A shift of the extensional direction is assumed to occur after the deposition of the Middle Series. This new configuration induced seaward tilting of the whole volcanic pile toward the southeast. It seems that a clear differ- 


\section{Selected fracture zones}

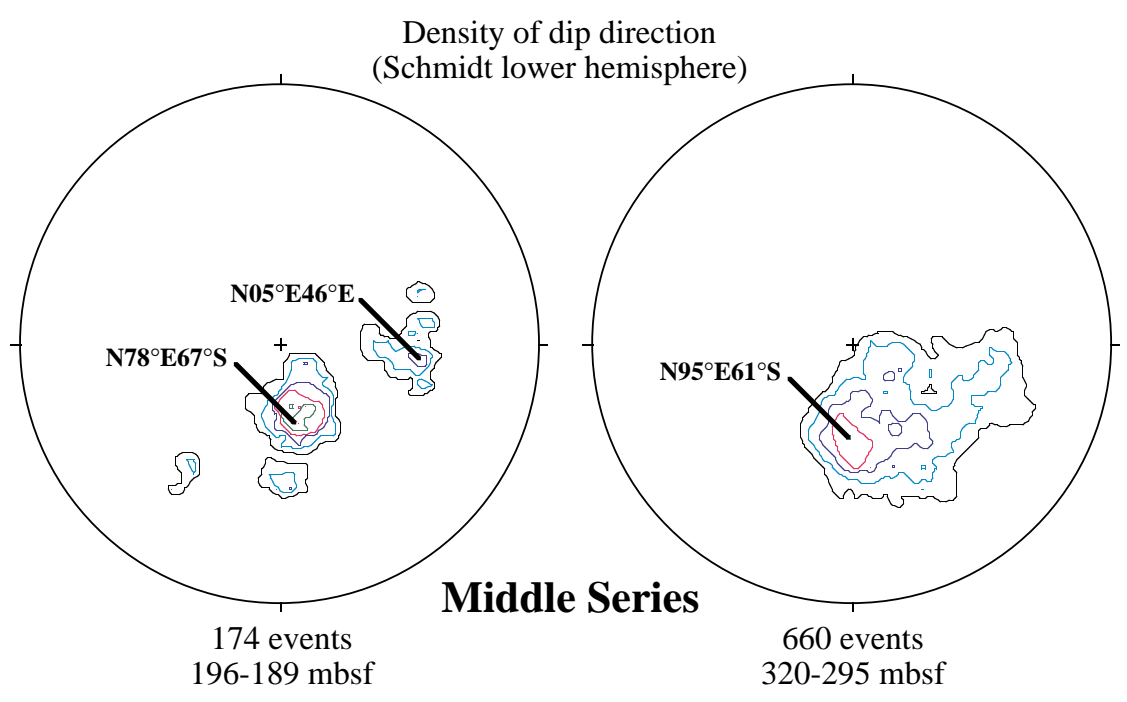

Figure 13. Density of dip directions of selected fracture zones at Hole 917A.

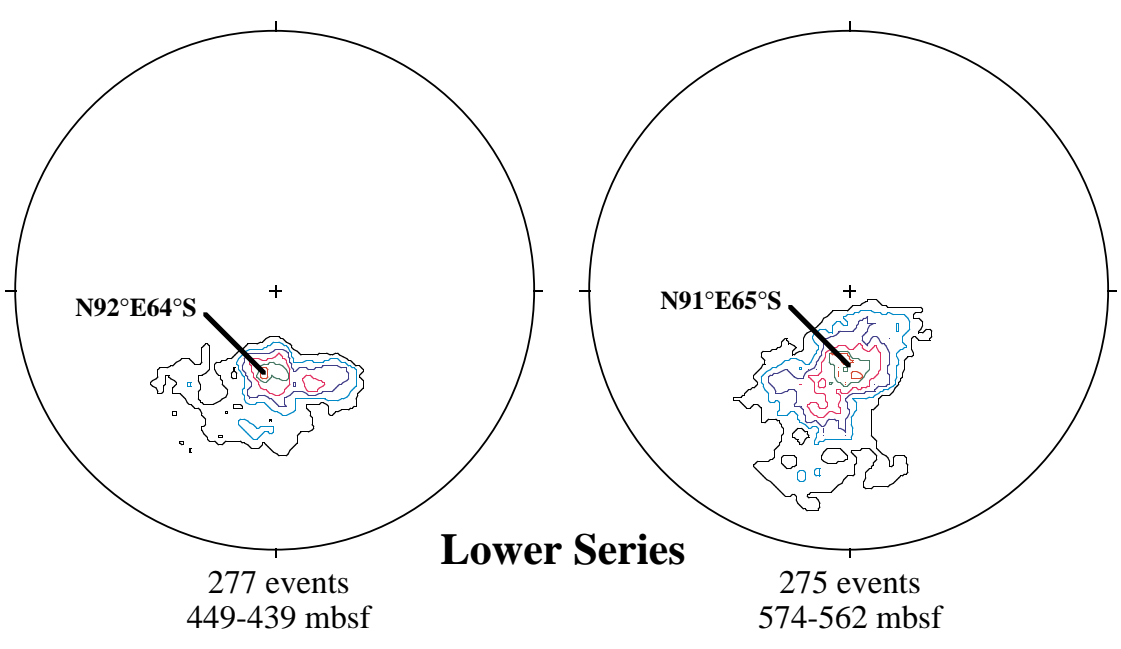

ence exists between the structural data of the Upper Series and those of the older series. One therefore suggests that a tectonic unconformity is located at the boundary between the Middle and the Upper Series. This interval, associated with a thin sediment layer, also marks a change from magmatic products having a residence time in, and reaction with, the continental crust, to noncontaminated Icelandic type magmatism (Fitton et al., Chap. 28, this volume). As a consequence, this boundary is assumed to correspond to the final breakup both in tectonic and magmatic senses.

\section{CONCLUSION}

The detailed analysis of FMS borehole imagery recorded in Hole 917A has yielded a precise description of the fracture pattern within $425 \mathrm{~m}$ of drilled lavas and outlines the tilting history of the oldest and most landward part of the basalts within the southeast Greenland SDRS. Both fracture pattern and tilting history favor north-south extension during the formation of the Lower and Middle Series lavas followed by a shift to northwest-southeast extension in the Upper Series lavas. Consequently, a major tectonic change is identified and supports the fundamental nature of boundary between the Middle and Upper Series lavas.

\section{ACKNOWLEDGMENTS}

We would like to thank Schlumberger Paris for making available at academic rates the FMS processing and analysis software. This work was supported by the "Marine Geosciences" ODP support program of CNRS in France. Many thanks are due to Dr. Philippe Pezard and to Pascal Corotti for constructive comments, and special mention to Dr. Bernard Legall for our discussions during the "Survival Cruise." The critical and careful review from Dr. Hans Christian Larsen and Dr. Sverre Planke greatly improved the content of this manuscript.

\section{REFERENCES}

Agrinier, P., and Agrinier, B., 1994. A propos de la connaissance de la profondeur à laquelle vos énchantillons sont collectés dans les forages. C. $R$. Acad. Sci., Ser. 2., 318:1615-1622.

Bell, J.S., and Gough, D.I., 1979. Northeast-southwest compressive stress in Alberta: evidence from oil wells. Earth Planet. Sci. Lett., 45:475-482.

Budkewitsch, P., and Robin, P.Y., 1994. Modelling the evolution of columnar joints. J. Volcanol. Geotherm. Res., 59:219-239.

Demant, A., Cambray, H., Vandamme, D., and Leg 152 Shipboard Scientific Party, 1995. Lithostratigraphy of the volcanic sequences at Hole 917A, 
Leg 152, Southeast Greenland margin. J. Geol. Soc. London, 152:943946.

Eldholm, O., Thiede, J., and Taylor, E., 1989. Evolution of the Vøring volcanic margin. In Eldholm, O., Thiede, J., Taylor, E., et al., Proc. ODP, Sci. Results, 104: College Station, TX (Ocean Drilling Program), 1033-1065.

Hardee, H.C., 1980. Solidification in Kilauea Iki lava lake. J. Volcanol. Geotherm. Res., 7:211-223.

Joppen, M., and White, R.S., 1990. The structure and subsidence of Rockall Trough from two-ship seismic experiments. J. Geophys. Res., 95:1982119837.

Larsen, H.C., 1990. The East Greenland Shelf. In Grantz, A., Johnson, G.L., and Sweeney, J.F. (Eds.), The Arctic Ocean Region. Geol. Soc. Am., Geol. of North Am. Ser., L:185-210.

Larsen, H.C., Saunders, A.D., Clift, P.D., et al., 1994. Proc. ODP, Init. Repts., 152: College Station, TX (Ocean Drilling Program).

Lüthi, S.M., and Banavar, J.R., 1988. Application of borehole images to three-dimensional geometric modeling of eolian sandstone reservoirs, Permian Rotliegende, North Sea. AAPG Bull., 72:1074-1089.

Lüthi, S.M., and Souhaité, P., 1990. A method for fracture extraction and width determination from electrical borehole scans. Geophysics, 55:821833.

Morin, R.H., Newmark, R.L., Barton, C.A., and Anderson, R.N., 1990. State of lithospheric stress and borehole stability at Deep Sea Drilling Project Site 504B, eastern Equatorial Pacific. J. Geophys. Res., 95:9293-9303.

Mutter, J.C., Talwani, M., and Stoffa, P.L., 1982. Origin of seaward-dipping reflectors in oceanic crust off the Norwegian margin by "subaerial seafloor spreading." Geology, 10:353-357.
Newmark, R.L., Anderson, R.N., Moos, D., and Zoback, M.D., 1985. Sonic and ultrasonic logging of Hole 504B and its implications for the structure, porosity, and stress regime of the upper $1 \mathrm{~km}$ of the oceanic crust. In Anderson, R.N., Honnorez, J., Becker, K., et al., Init. Repts. DSDP, 83: Washington (U.S. Govt. Printing Office), 479-510.

Pezard, P., Lovell, M., and ODP Leg 126 Shipboard Scientific Party, 1990. Downhole images: electrical scanning reveals the nature of subsurface oceanic crust. Eos, 71:709, 718.

Pollard, D.D., 1987. Elementary fracture mechanics applied to the structural interpretation of dykes. In Halls, H.C., and Fahrig, W.F. (Eds.), Mafic Dyke Swarms. Geol. Assoc. Can., Spec. Pap., 34:5-24.

Srivastava, S.P., and Tapscott, C.R., 1986. Plate kinematics of the North Atlantic. In Vogt, P.R., and Tucholke, B.E. (Eds.), The Western North Atlantic Region. Geol. Soc. Am., Geol. North Am. Ser., M:379-404.

White, R.S., and McKenzie, D., 1989. Magmatism at rift zones: the generation of volcanic continental margins and flood basalts. J. Geophys. Res., 94:7685-7729.

Date of initial receipt: 4 November 1995

Date of acceptance: 29 May 1996

Ms 152SR-237 